\title{
PENGARUH PEMBERIAN PAKAN CACING SUTERA (Tubifex sp.) DAN Daphnia sp. TERHADAP PERTUMBUHAN DAN TINGKAT KELANGSUNGAN HIDUP LARVA IKAN LELE SANGKURIANG (Clarias gariepinus)
}

\section{THE FEED EFFECT OF BLOODWORM (Tubifex sp.) AND Daphnia sp. ON GROWTH AND SURVIVAL RATE OF SANGKURIANG CATFISH (Clarias gariepinus) LARVAE}

\author{
Oktoviandy Eka Surya Prasetya ${ }^{1}$, Muarif ${ }^{2}$, Fia Sri Mumpuni ${ }^{2}$ \\ ${ }^{1}$ Sekolah Vokasi, IPB University Bogor \\ ${ }^{2}$ Program Studi Akuakultur, Fakultas Pertanian, Universitas Djuanda Bogor \\ J1. Tol Ciawi 1, Pos 35 Bogor 16720 \\ Email: oktoviandyekasp.@gmail.com
}

\begin{abstract}
This study is aim to determine feed affect of blood worm and Daphnia sp. on growth and survival rate of Clarias sp. larvae. The experiment was conducted in February 2019-Oktober 2019 at PT. Arwana Cibubur, Cimanggis, Depok, West Java. Completely randomized design is used in this study which is 2 different treatments and 5 replications; A (Daphnia sp. on first 3 days keeping then been continued with blood worm) and B (blood worm). Obeservational parameter in this study are growth and survival rate of larvae by measuring weight and body length total. The growth were increased in both A and B treatment show the best growth result with an average value of the increases body weight is $23,56 \%$ and the increases body length is $1,8 \mathrm{~cm}$. The A treatment show the best survival rate result with an average is $83,20 \%$. Water quality during experiment were measured; temperature $24-27^{\circ} \mathrm{C}, \mathrm{pH} 8,4-8,7, \mathrm{DO} 9,7-15,2 \mathrm{mg} / \mathrm{L}, \mathrm{NH}_{3}$ 0,00-0,20 mg/L, and $\mathrm{NO}_{2}<0,3-1,6 \mathrm{mg} / \mathrm{L}$.
\end{abstract}

Keywords: sangkuriang catfish, blood worm, Daphnia sp., growth rate, survival rate

\begin{abstract}
ABSTRAK
Penelitian ini bertujuan untuk mengetahui pengaruh pemberian pakan cacing sutera dan Daphnia sp. terhadap pertumbuhan dan tingkat kelangsungan hidup larva ikan lele sangkuriang. Penelitian ini dilakukan pada bulan Februari 2019 - Oktober 2019, bertempat di PT. Arwana Cibubur, Cimanggis, Depok, Jawa Barat.. Penelitian ini menggunakan larva ikan lele sangkuriang dengan 2 perlakuan yang berbeda dengan 5 kali ulangan. Sebagai perlakuan adalah A (pemberian Daphnia sp. pada 3 hari pertama pemeliharaan dilanjut cacing sutera) dan B (pemberian cacing sutera). Parameter yang diamati meliputi tingkat kelangsungan hidup dan laju pertumbuhan meliputi pengukuran panjang total dan berat bobot ikan. Hasil penelitian menunjukan perubahan pada laju pertumbuhan ikan pada hari ke-14 terlihat selama pengukuran laju pertumbuhan bertambah pada perlakuan A dan B. Pengukuran laju pertumbuhan bobot dan panjang terbaik pada perlakuan B dengan nilai rata-rata sebesar $23,56 \%$ dan $1,8 \mathrm{~cm}$. Sedangkan untuk tingkat kelangsungan hidup terbaik pada perlakuan A yaitu rata-rata yang didapatkan sebesar $\pm 83,20 \%$. Kualitas air yang didapatkan selama penelitian yaitu, suhu $24-27^{\circ} \mathrm{C}, \mathrm{pH} 8,4-8,7$, DO 9,7-15,2mg/L, NH3 0,00-0,20 mg/L, dan $\mathrm{NO}_{2}<0,3-1,6 \mathrm{mg} / \mathrm{L}$.
\end{abstract}

Kata Kunci: ikan lele sangkuriang, cacing sutera, Daphnia sp., laju pertumbuhan, tingkat kelangsungan hidup

Oktoviandy Eka Surya Prasetya, Muarif, Fia Sri Mumpuni. 2020. Pengaruh Pemberian Pakan Cacing Sutera (Tubifex sp.) dan Daphnia sp. terhadap Pertumbuhan dan Tingkat Kelangsungan Hidup Larva Ikan Lele Sangkuriang (Clarias gariepinus). Jurnal Mina Sains 6(1): 8-16.

\section{PENDAHULUAN}

Ikan lele merupakan salah satu produk perikanan yang sangat digemari masyarakat. Gizinya yang tinggi dan harganya yang terjangkau membuat permintaan masyarakat terhadap ikan lele semakin meningkat. Berkembangnya industri kuliner berbahan dasar ikan lele di Indonesia membuktikan besarnya peluang pasar ikan lele. Peningkatan permintaan terhadap ikan lele mendorong pelaku pembudidaya ikan lele untuk 
meningkatkan jumlah produksi. Ketersediaan benih unggul yang kontinu merupakan faktor kunci dalam usaha meningkatkan produksi perikanan (Suprapto et al. 2012). Penggunaan benih unggul dalam usaha pembesaran ikan lele dapat menekan angka kematian benih,menurunkan resiko penyakit, dan pertumbuhan yang relatif lebih cepat sehingga jumlah produksi meningkat. Kebutuhan benih unggul dapat terpenuhi dengan prosedur pembenihan yang baik. menurut Idawati et al. (2018) dan Tjodi et al. (2016) pemeliharaan pada fase pembenihan merupakan fase kritis dalam kegiatan budidaya. Hal ini terjadi karena tingginya kematian dan kanibalisme pada saat fase larva dan benih. Peralihan pakan dari endogenous feeding menjadi exogenous feeding menjadi salah satu faktor tingginya kematian dan kanibalisme larva. Menurut Tjodi et al. (2016), pemilihan pakan yang tepat merupakan kunci keberhasialn kegiatan pembenihan.

Mayoritas pelaku usaha pembenihan ikan lele sangkuriang saat ini memilih cacing sutera sebagai pakan pertama yang diberikan setelah kuning telur habis. Menurut Suprapto et al. (2012) larva lele yang diberikan pakan cacing sutera memiliki laju pertumbuhan terbaik dibandingkan larva lele yang diberikan Artemia sp., Daphnia sp., Moina sp., dan Chironomus sp. dengan tingkat kelangsungan hidup tertinggi diperoleh larva yang diberikan pakan Artemia sp. Saat ini kontinuitas cacing sutera masih bergantung pada hasil tangkapan alam. Menurut Setyaningrum et al. (2016) Musim hujan membuat ketersediaan cacing sutera di alam berkurang karena cacing terbawa arus saat intensitas hujan tinggi. Kelangkaan cacing sutera dapat menghambat kegiatan pembenihan sehingga produksi yang dihasilkan kurang maksimal. Salah satu solusi permasalahan ini adalah melakukan kombinasi pakan cacing sutera dengan pakan alami sejenis.

Kriteria pakan alami yang baik untuk larva adalah kandungan gizi tinggi, sesuai dengan bukaaan mulut larva, kontinuitas terjaga, dan memiliki warna yang menarik perhatian larva (Suprapto et al. 2012). Salah satu jenis pakan alami yang masuk dalam kriteria tersebut adalah Daphnia sp. Menurut Mufidah et al. (2009) larva lele afrika yang diberikan pakan Daphnia sp. menghasilkan tingkat kelangsungan hidup yang baik. kontinuitas Daphnia sp. dapat terjaga karena Daphnia sp. mudah untuk dibudidayakan. Biaya yang dibutuhkan untuk budidaya Daphnia sp. tergolong murah dibandingkan dengan jenis pakan alami lain seperti Artemia sp. dan tidak membutuhkan lahan yang luas.oleh karena itu perlu dilakukan penelitian lebih lanjut pengaruh pemberian Daphnia sp. dan cacing sutera terhadap pertumbuhan dan tingkat kelangsungan hidup larva ikan lele sangkuriang.

\section{METODE PENELITIAN}

\section{Waktu dan Tempat}

Penelitian ini dilaksanakan pada bulan Februari 2019 sampai Oktober 2019 di PT. Arwana Cibubur, Cimanggis, Depok, Jawa Barat.

\section{Alat dan Bahan}

Alat yang digunakan untuk penelitian tentang laju pertumbuhan adalah penggaris, timbangan digital, serokan, dan alat tulis. Pengukuran kualitas air dilakukan menggunakan DO meter, $\mathrm{pH}$ meter, test kit dan termometer. Wadah percobaan adalah akuarium $100 \mathrm{~cm} \times 100 \mathrm{~cm} \times 35 \mathrm{~cm}$ sebanyak 10 unit wadah pemeliharaan.

Bahan-bahan yang digunakan yaitu 20.000 ekor larva ikan lele sangkuriang yang berukuran berumur 2 hari, cacing sutera, dan Daphnia sp.

\section{Rancangan Penelitian}

Penelitian ini menggunakan RAL (Rancangan Acak Lengkap) dengan 2 perlakuan dan 5 kali ulangan. Adapun perlakuan yang digunakan pada penelitian ini adalah sebagai berikut:

1. Perlakuan A: Pemberian Daphnia sp. selama 3 hari dan dilanjutkan dengn pemberian pakan cacing sutera selama 11 hari. 
2. Perlakuan B: Pemberian cacing sutera selama 14 hari.

\section{Prosedur Penelitian Persiapan Wadah}

Wadah penelitian larva ikan lele sangkuriang menggunakan akuarium berukuran $100 \mathrm{~cm} \times 100 \mathrm{~cm} \times 35 \mathrm{~cm}$ sebanyak 10 unit. Sebelum digunakan, akuarium didesinfeksi terlebih dahulu menggunakan larutan Kalium Permanganat dengan dosis $20 \mathrm{ppm}$ dan dibilas serta dikering udarakan selama 1 hari. Akuarium kemudian diisi air setinggi $30 \mathrm{~cm}$ dan diendapkan selama 3 hari sebelum penebaran larva.

\section{Penebaran Larva}

Larva yang disiapkan diukur berat dan panjangnya sebelum diaklimatisasi. Aklimatisasi dilakukan dengan menaruh baskom plastik yang telah di isi larva yang telah di hitung di atas akuarium uji. Kemudian baskom plastik diisi sedikit air dari akuarium. Setelah di diamkan selama 10 menit larva ditebar secara perlahan ke dalam akuarium.

\section{Pemeliharaan Larva}

Larva yang telah ditebar dipelihara selama 2 minggu. Selama masa pemeliharaan dilakukan pemberian pakan sesuai perlakuan sebanyak 3 kali sehari dengan metode ed libitum. Selama pemeliharaan dilakukan pengontrolan kesehatan dan kualitas air setiap pukul 06:00. Penyifonan dilakukan setiap pagi dengan mengurangi ketinggian air sebanyak $5 \mathrm{~cm}$ dan dilakukan penambahan air hingga tinggi air kembali seperti semula. Kegiatan sampling dilakukan setiap 1 minggu sekali dengan pengambilan sampel $10 \%$ dari total populasi pada setiap akuarium.

\section{Pemberian Pakan}

Pemberian pakan dilakukan pada pukul 07:00, 13:00, dan 20:00 WIB. Pakan cacing sutera yang akan diberikan dicacah halus terlebih dahulu sebelum diberikan. Sementara pakan Daphnia sp. bisa langsung ditebar ke akuarium larva.

\section{Pemanenan Larva}

Pemanenan larva dilakukan setelah 14 hari pemeliharaan. Pemanenan dilakukan dengan penimbangan bobot total populasi, perhitungan jumlah total populasi, dan pengukuran panjang sebanyak 200 ekor/akuarium.

\section{Parameter Uji \\ Pertumbuhan bobot per hari (SGR) \\ Menurut Elliot dan Hurley (1995) perhitungan pertumbuhan bobot per hari dapat menggunakan rumus:}

\section{$\mathrm{SGR}=\frac{\left(\operatorname{Ln} \mathrm{W}_{\mathrm{t}}-\ln \mathrm{W}_{0}\right)}{\mathrm{t}} \quad \times 100 \%$}

Keterangan:

$\mathrm{SGR}=$ Pertumbuhan bobot per hari $(\% /$ hari $)$

$\mathrm{W}_{\mathrm{t}}=$ Bobot ikan pada hari ke-t $(\mathrm{g})$

$\mathrm{L}_{0}=$ Bobot ikan pada hari ke-0 $(\mathrm{g})$

$\mathrm{t}=$ Periode pengamatan (hari)

\section{Pertumbuhan Panjang Tubuh}

Panjang tubuh diukur dari ujung mulut hingga ekor (panjang total). Menurut Effendie (1979) rumus untuk menentukan pertumbuhan panjang ikan adalah

Keterangan :

$$
\mathbf{P P M}=\mathbf{P}_{\mathbf{t}}-\mathbf{P}_{\mathbf{0}}
$$

$\mathrm{P}_{\mathrm{t}}=$ Panjang larva rata-rata pada hari ke $\mathrm{t}$ $(\mathrm{cm})$

$\mathrm{P}_{0}=$ Panjang larva rata-rata pada hari ke 0 $(\mathrm{cm})$

\section{Tingkat kelangsungan hidup (SR)}

Penghitungan kelangsungan hidup (SR) dengan menggunakan rumus (Elliot dan Hurley. 1995) yaitu:

$$
\mathrm{SR}=\frac{\mathbf{N}_{\mathrm{t}}}{\mathbf{N}_{\mathrm{o}}} \times 100 \%
$$

Keterangan :

$\mathrm{SR}=$ Tingkat kelangsungan hidup $(\%)$

$\mathrm{N}_{\mathrm{t}}=\sum$ ikan saat akhir penelitian

$\mathrm{N}_{0}=\sum$ ikan saat awal penelitian

\section{Kualitas Air}

Parameter kualitas air yang diukur meliputi suhu, $\mathrm{pH}, \mathrm{DO}$ dan amonia. Alat ukur yang digunakan yaitu $\mathrm{pH}$ meter, DO meter, Termometer dan Test kit. Pengukuran suhu, 
DO dan $\mathrm{pH}$ dilakukan setiap hari selama pemeliharaan. Sementara pengukuran amoniak dilakukan setiap 4 hari sekali.

\section{Analisis Data}

Data yang didapatkan dianalisis menggunakan uji t.

\section{HASIL DAN PEMBAHASAN}

\section{Laju Pertumbuhan Bobot per Hari Larva Ikan Lele Sangkuriang}

Pertumbuhan bobot per hari terbaik pada minggu pertama didapatkan pada perlakuan B yaitu rata-rata $\pm 26,49 \%$ (Tabel 1 ). Pada minggu kedua perlakuan A memiliki persentase pertumbuhan terbaik dengan ratarata $\pm 24,64 \%$. Sementara pertumbuhan bobot terbaik dari awal penelitian sampai panen didapatkan pada perlakuan cacing sutera dengan rata-rata sebesar $\pm 23,56 \%$.

Hasil uji t pada pertumbuhan bobot per hari larva pada minggu pertama dan kedua pemeliharaan menunjukkan hasil berbeda nyata $(\mathrm{P}<0,05)$ antara perlakuan $\mathrm{A}$ dengan perlakuan B sementara pada hasil uji t SGR selama masa pemeliharaan tidak menunjukkan hasil bebeda nyata $(\mathrm{P}>0.05)$. pada minggu pertama perlakuan B memiliki nilai SGR (Survival Growth Rate) terbaik dengan rata-rata $\pm 26,49 \%$. Sedangkan pada minggu kedua perlakuan A memiliki nilai SGR terbaik dengan nilai $\pm 26,64 \%$. Sementara perlakuan B memiliki nilai SGR tertinggi selama pemeliharaan dengan ratarata $\pm 23,56 \%$. Hal ini terjadi diduga karena Nurtisi yang terdapat pada cacing sutera lebih baik dari Daphnia sp. Terlihat pada perlakuan A mengalami kenaikan nilai SGR dan pertumbuhan panjang setelah diberikan pakan cacing sutera. Perbedaan konsentrasi enzim eksogen yang terdapat pada Daphnia sp. dan cacing sutera dapat mempengaruhi daya cerna pada larva. Tubuh Daphnia sp. mengandung zat khitin yang mempengaruhi daya cerna dan pertumbuhan perlakuan A pada minggu pertama pemeliharaan.

Menurut Nazhiroh et al. (2019) jenis dan kualitas pakan yang digunakan mempenagruhi pertumbuhan ikan. Gizi yang terkandung cacing sutera sangat baik untuk memacu pertumbuhan larva. Menurut Hariati (2010) cacing sutera mengandung 51,9\% protein, 20,3\% karbohidrat, 22,3\% lemak, dan $5,3 \%$ bahan abu. Sementara Daphnia sp. memiliki persentase protein $50 \%$ dan lemak 4-5\% (Pangkey, 2018). Pertumbuhan ikan dipengaruhi oleh jumlah protein yang terkandung di dalam pakan (Anggraeni dan Abdulgani, 2013). Kadar protein yang terkandung di dalam cacing sutera sesuai dengan jumlah protein yang dibutuhkan oleh larva Menurut Nurhayati et al. (2014) larva ikan lele dumbo yang diberikan pakan cacing sutera menghasilkan laju pertumbuhan lebih tinggi $(22,56 \%)$ dibandingkan pakan buatan $(19,94 \%)$. Cacing sutera yang bersifat autolisis serta mengandung berbagai enzim eksogen yang merangsang pembentukan enzim pencernaan membuat pertumbuhan larva ikan lele dumbo menjadi lebih baik. Menurut Pangkey (2015) Daphnia sp. mengandung beberapa enzim pencernaan yang berfungsi sebagai enzim eksogen untuk membantu kecernaan larva.

Perbedaan jenis pakan yang diberikan dapat mempengaruhi kecernaan dan pertumbuhan ikan. Hal ini dikarenakan adanya perbedaan zat dan nutrisi yang dikandung oleh setiap pakan.Perlakuan A memiliki laju pertumbuhan yang lebih rendah dibandingkan perlakuan $B$ pada minggu pertama. Hal ini disebabkan adanya perbedaan kandungan zat dan nutrisi yang terkandung pada kedua jenis pakan tersebut. Menurut Mulyadi et al. (2011) kualitas pakan bukan hanya dinilai dari kandungan gizi, tetapi juga kemampuan ikan dalam mencerna dan menyerap pakan untuk diolah menjadi energi. Cacing sutera tidak memiliki kandungan serat kasar sehingga mudah dicerna untuk larva yang memiliki sistem pencernaan belum sempurna (Suprapto et al. 2012). Enzim eksogen yang terkandung di dalam cacing sutera dapat mempengaruhi perkembangan kelenjar pencernaan berupa pankreas untuk memproduksi enzim pencernaan di dalam tubuh (Farhoudi et al. 2013). Menurut Tjodi et al. (2016) cacing sutera mengandung beberapa jenis enzim 
pencernaan yang berfungsi sebagai enzim eksogen untuk meningkatkan daya cerna larva. Menurut Pangkey (2015) Daphnia sp. memiliki kandungan enzim pencernaan yang dapat berperan sebagai enzim eksogen bagi larva. Tetapi, Daphnia sp. memiliki kandungan khitin pada bagian luar tubuhnya. Khitin merupakan zat berbentuk kristal dan tidak larut dalam larutan asam kuat sehingga sulit dicerna oleh tubuh (Retnosari, 2007). Zat khitin dapat menghambat penyerapan nutrien yang terkandung di dalam pakan. Menurut Rachmawati dan Istiyanto (2013) semakin besar persentase kandungan khitin pada pakan dapat meningkatkan nilai FCR dan menurunkan efisiensi pakan.
Jumlah pakan yang diberikan dapat mempengaruhi pertumbuhan ikan. Persentase kandungan gizi yang diberikan larva tergantung jumlah pakan. Menurut Triyanto et al. (2016) pemberian jumlah pakan yang tepat memberikan hasil pertumbuhan yang baik. frekuensi dan persentase pakan yang diberikan harus disesuaikan dengan umur dan stadia ikan. Menurut Triyanto et al. (2015) pemberian dosis pakan yang kurang tepat akan berdampak negatif bagi ikan dan lingkungannya. Pada perlakuan A total pakan yang diberikan selama penelitian adalah 5.376 gram. Sementara jumlah pakan yang diberikan untuk perlakuan B adalah 7.200 gram.

Tabel 1 Pertumbuhan Bobot Per Hari (\%) Larva Ikan Lele Sangkuriang

\begin{tabular}{ccccccc}
\hline \multirow{2}{*}{ Ulangan } & \multicolumn{2}{c}{ Minggu 0- 1 } & \multicolumn{2}{c}{ Minggu 1-2 } & \multicolumn{2}{c}{ Minggu 0-2 } \\
\cline { 2 - 7 } & $\begin{array}{c}\mathrm{A} \\
\text { (Daphnia) }\end{array}$ & $\begin{array}{c}\mathrm{B} \\
\text { (Cacing sutera) }\end{array}$ & $\begin{array}{c}\mathrm{A} \\
\text { (Daphnia) }\end{array}$ & $\begin{array}{c}\mathrm{B} \\
\text { (Cacing sutera) }\end{array}$ & $\begin{array}{c}\mathrm{A} \\
\text { (Daphnia) }\end{array}$ & $\begin{array}{c}\text { B } \\
\text { (Cacing sutera) }\end{array}$ \\
\hline 1 & 19,8 & 22,99 & 26,74 & 23,18 & 23,27 & 23,09 \\
\hline 2 & 17,2 & 24,78 & 27,28 & 20,52 & 22,24 & 22,65 \\
\hline 3 & 19,07 & 28,59 & 26,91 & 21,18 & 22,99 & 24,89 \\
\hline 4 & 18,3 & 26,37 & 19,80 & 17,90 & 19,05 & 22,13 \\
\hline 5 & 21,49 & 29,71 & 22,67 & 20,42 & 22,08 & 25,06 \\
\hline Rata-rata & 19,17 & 26,49 & 24,68 & 20,64 & 21,93 & 23,56 \\
\hline
\end{tabular}

\section{Pertumbuhan Panjang}

Hasil laju pertumbuhan panjang larva ikan lele sangkuriang selama penelitian dapat dilihat pada Tabel 2. Perlakuan B memiliki pertumbuhan panjang terbaik pada minggu pertama dengan rata-rata sebesar $\pm 0,8 \mathrm{~cm}$. Hasil uji $t$ pada laju pertumbuhan panjang larva ikan lele sangkuriang pada minggu pertama menunjukkan perbedaan nyata $(p$ $<0,05)$. Sementara pertumbuhan panjang terbaik pada minggu kedua didapatkan pada perlakuan A dengan rata-rata sebesar $\pm 1,0$ $\mathrm{cm}$. Hasil uji t pertumbuhan panjang pada minggu kedua menunjukkan hasil tidak berbeda nyata $(p>0,05)$. Larva yang diberi perlakuan $\mathrm{B}$ memiliki pertumbuhan panjang terbaik selama masa pemeliharaan dengan rata-rata sebesar $\pm 1,76 \mathrm{~cm}$. Hasil uji t pada pertumbuhan panjang larva selama penelitian menunjukkan hasil berbeda nyata $(\mathrm{p}<0,05)$.
Pada minggu pertama pemeliharaan laju pertumbuhan terbaik didapatkan pada perlakuan B dengan rata-rata nilai $\pm 0,8 \mathrm{~cm}$. Hal ini diduga karena kandungan nutrisi cacing sutera lebih lengkap dibandingkan Daphnia sp. walaupun memiliki kandungan protein yang hampir sama. Sedangkan pada minggu kedua perlakuan A (Daphnia sp.) memiliki laju pertumbuhan terbaik dengan nilai rata rata $\pm 1 \mathrm{~cm}$. Hal ini diduga karena adanya overlapping pakan pada perlakuan A dari Daphnia sp. menjadi cacing sutera runcah sehingga pertumbuhan panjang meningkat. Sementara pertumbuhan panjang terbaik selama masa pemeliharaan diperoleh perlakuan Cacing sutera dengan panjang ratarata $\pm 1,8 \mathrm{~cm}$.

Energi banyak dibutuhkan ketika ikan baru memasuki fase larva. Karena pada fase ini terjadi penyempurnaan organ dan pertumbuhan ikan. Salah satu zat yang 
dibutuhkan larva untuk dikonversikan menjadi energi adalah protein. Menurut Tjodi et al. (2016) penambahan persentase protein dan dosis pakan yang diberikan pada ikan lele harus disesuaikan dengan ukuran dan jumlah ikan yang dipelihara. Sehingga dapat mendukung laju pertumbuhan dan kesehatan ikan. Cacing sutera mengandung persentase protein yang lebih tinggi dibandingkan Daphnia sp. dan dapat memenuhi jumlah protein yang dibutuhkan larva. Hal ini menyebabkan larva yang diberi pakan cacing sutera runcah memiliki laju pertumbuhan panjang lebih baik dibandingkan larva yang diberi pakan Daphnia sp. Menurut Naziroh et al. (2019) kualitas pakan sangat ditentukan dengan jumlah nutrisi yang dikandungnya yang dapat digunakan untuk pertumbuhan dan energi yang dibutuhkan ikan.

Tabel 2 Pertumbuhan Panjang Mutlak pada Larva Ikan Lele Sangkuriang (cm)

\begin{tabular}{ccccccc}
\hline \multirow{2}{*}{ Ulangan } & \multicolumn{3}{c}{ Daphnia } & \multicolumn{3}{c}{ Cacing sutera } \\
\cline { 2 - 7 } & $\begin{array}{c}\text { Minggu } \\
\text { ke 1 }\end{array}$ & $\begin{array}{c}\text { Minggu } \\
\text { ke 2 }\end{array}$ & $\begin{array}{c}\text { Minggu } \\
0-2\end{array}$ & $\begin{array}{c}\text { Minggu } \\
\text { ke 1 }\end{array}$ & $\begin{array}{c}\text { Minggu } \\
\text { ke 2 }\end{array}$ & $\begin{array}{c}\text { Minggu } \\
0-2\end{array}$ \\
\hline 1 & 0,6 & 1,0 & 1,6 & 0,7 & 1,0 & 1,7 \\
\hline 2 & 0,6 & 1,0 & 1,6 & 0,8 & 0,9 & 1,7 \\
\hline 3 & 0,7 & 0,9 & 1,6 & 0,8 & 0,9 & 1,7 \\
\hline 4 & 0,8 & 1,0 & 1,7 & 0,9 & 0,9 & 1,8 \\
\hline 5 & 0,6 & 1,1 & 1,6 & 1,0 & 1,0 & 2,0 \\
\hline Rata-rata & 0,6 & 1 & 1,6 & 0,8 & 0,9 & 1,8 \\
\hline
\end{tabular}

\section{Tingkat Kelangsungan Hidup}

Tingkat kelangsungan hidup larva ikan lele sangkuriang dapat dilihat pada Tabel 3.Tingkat kelangsungan hidup terbaik larva ikan lele sangkuriang didapatkan pada perlakuan A dengan persentase $\pm 83,20 \%$. Hasil uji t pada tingkat kelangsungan hidup ikan lele sangkuriang menunjukkan hasil berbeda nyata $(\mathrm{p}<0,05)$. Hal ini diduga karena ukuran Daphnia sp. yang diberikan sesuai dengan bukaan mulut larva. Sementara ukuran cacing sutera runcah yang diberikan pada larva tidak seragam. Hal ini menyebabkan tingkat kelangsungan hidup larva ikan lele di minggu pertama pada perlakuan cacing sutera menurun karena kanibalisme.

Pemilihan jenis pakan alami yang diberikan untuk larva dapat mempengaruhi tingkat kelangsungan hidup dan pertumbuhan larva. Menurut Satyantini et al. (2008) jumlah kanibalisme dapat ditekan dengan pemilihan pakan alami yang tepat. Daphnia sp. dan cacing sutera merupakan pakan alami yang memiliki kandungan protein cukup tinggi sehingga bisa memenuhi kebutuhan nutrisi larva. Menurut Suprapto et al. (2012) kriteria pakan alami yang baik diberikan larva adalah mampu memenuhi kebutuhan gizi larva, sesuai dengan bukaan mulut larva, dan mampu menarik perhatian larva. Daphnia sp. memiliki ukuran yang lebih kecil dibandingkan cacing sutera runcah sehingga lebih mudah dimakan oleh larva. Selain itu Daphnia sp. memiliki pergerakan yang aktif dan warna yang lebih menarik dibandingkan cacing sutera runcah. Hal ini membuat kanibalisme yang terjadi pada perlakuan A lebih rendah dibandingkan perlakuan $\mathrm{B}$ sehingga perlakuan A memiliki persentase kelangsungan hidup yang tinggi. Menurut Suprapto et al. (2012) tingkat kelangsungan hidup larva ikan lele yang diberikan pakan Artemia sp. lebih tinggi $(69,85 \%)$ dibandingkan larva lele yang diberikan pakan cacing sutera $(56,63 \%)$. Menurut Raharjo et al. (2016) pergantian pakan (overlapping) berpengaruh terhadap pertumbuhan dan kelangsungan hidup ikan. Pergantian pakan dilakukan untuk menyesuaikan ukuran dan kebutuhan gizi yang dibutuhkan terhadap pertambahan stadia ikan. 
Tabel 3 Tingkat Kelangsungan Hidup Larva Ikan Lele Sangkuriang

\begin{tabular}{ccc}
\hline \multirow{2}{*}{ Ulangan } & \multicolumn{2}{c}{ Perlakuan } \\
\cline { 2 - 3 } & $\begin{array}{c}\mathrm{A} \\
(\text { Daphnia) }\end{array}$ & $\begin{array}{c}\mathrm{B} \\
\text { (Cacing sutera) }\end{array}$ \\
\hline 1 & $84 \%$ & $68 \%$ \\
\hline 2 & $79,10 \%$ & $66,70 \%$ \\
\hline 3 & $87,35 \%$ & $70,25 \%$ \\
\hline 4 & $89,45 \%$ & $70,35 \%$ \\
\hline 5 & $76,10 \%$ & $69,80 \%$ \\
\hline Rata-rata & $\pm 83,20 \%$ & $\pm 69 \%$
\end{tabular}

Menurut Raharjo et al. (2016) pergantian pakan dengan waktu yang tepat menyebabkan pertumbuhan dan kelangsungan hidup ikan meningkat. Pada perlakuan A pergantian pakan dimulai saat hari keempat pemeliharaan. Pergantian pakan larva dari Daphnia sp. menjadi cacing sutera runcah dilakukan karena diduga ukuran bukaan mulut larva sudah bisa memakan cacing sutera runcah. Hal ini menyebabkan perlakuan A memiliki tingkat kelangsungan hidup tertinggi dibandingkan dengan perlakuan B.

\section{Kualitas Air}

Selama penelitian parameter kualitas air yang diukur adalah suhu, $\mathrm{pH}, \mathrm{DO}$, nitrit $\left(\mathrm{NO}_{2}\right)$, dan ammonia $\left(\mathrm{NH}_{3}\right)$ dapat dilihat pada Tabel 4.

Tabel 4 Kualitas Air

\begin{tabular}{cccccc}
\hline \multirow{2}{*}{ Wadah } & \multicolumn{5}{c}{ Parameter } \\
\cline { 2 - 6 } & Suhu $\left({ }^{\circ} \mathrm{C}\right)$ & $\mathrm{pH}$ & $\begin{array}{c}\mathrm{DO} \\
(\mathrm{mg} / \mathrm{L})\end{array}$ & $\begin{array}{c}\mathrm{NH} 3 \\
(\mathrm{mg} / \mathrm{L})\end{array}$ & $\begin{array}{c}\mathrm{NO} 2 \\
(\mathrm{mg} / \mathrm{L})\end{array}$ \\
\hline A (Daphnia) & $24-27$ & $8,4-8,7$ & $9,7-15,2$ & $0.00-0,09$ & $<0,3-0,8$ \\
B (Cacing sutera) & $24-27$ & $8,4-8,7$ & $9,7-15,1$ & $0,00-0,2$ & $<0,3-1,6$ \\
\hline
\end{tabular}

Kualitas air merupakan faktor pendukung yang penting untuk menjaga kesehatan dan pertumbuhan ikan. Suhu, oksigen terlarut, dan $\mathrm{pH}$ dapat berpengaruh terhadap laju metabolisme tubuh di mana dapat meningkatkan aktivitas metabolisme dan dapat meningkatkan nafsu makan ikan (Zonneveld et al. 1991). Hasil pengukuran kualitas air selama penelitian masih tergolong normal untuk kelangsungan hidup larva ikan lele sangkuriang, yaitu suhu $24-27{ }^{\circ} \mathrm{C}, \mathrm{pH}$ 8,4-8,7, DO 9,7-15,1 mg/L, dan amoniak 00,2 mg/L. Menurut Boyd dan Licthkoppler (1979) kualitas air yang baik untuk ikan yang dibudidayakan di kolam adalah $\mathrm{pH}$ diatas 5, suhu $25-32{ }^{\circ} \mathrm{C}$, dan kadar amoniak di bawah 0,3mg/L. Perlakuan B memiliki kadar amoniak yang mendekati ambang batas normal. Hal ini disebabkan cacing sutera yang diberikan dalam kondisi tercacah dan mati sehingga menambah kandungan limbah organik yang terdapat pada lingkungan pemeliharaan. Menurut Boyd dan Licthkoppler (1979) kadar amoniak dapat mempengaruhi pertumbuhan, kesehatan dan kelangsungan hidup ikan. Hal ini terbukti dari tingkat kelangsungan hidup yang didapatkan pada perlakuan B lebih rendah dibandingkan dengan perlakuan A.

\section{KESIMPULAN DAN SARAN}

\section{Kesimpulan}

Berdasarkan hasil dan pembahasan dapat disimpulkan pemberian Daphnia sp. dan cacing sutera pada larva ikan lele sangkuriang berpengaruh nyata terhadap Pertumbuhan panjang per hari dan tingkat kelangsungan 
hidup larva. Nilai SGR tertinggi diperoleh pada perlakuan B (Cacing sutera). Sementara tingkat kelangsungan hidup terbaik dimiliki oleh perlakuan A (Daphnia). Kualitas air yang didapatkan selama penelitian yaitu, suhu 24$27{ }^{\circ} \mathrm{C}$, pH 8,4-8,7, DO 9,7-15,1 mg/L, dan amoniak 0-0,2 $\mathrm{mg} / \mathrm{L}$.

\section{Saran}

Perlu dilakukan penelitian lebih lanjut untuk mengetahui waktu overlapping yang baik pada larva ikan lele sangkuriang untuk peningkatan pertumbuhan dan kelangsungan hidup larva.

\section{DAFTAR PUSTAKA}

Anggraeni N, Abdulgani N. 2013. Pengaruh Pemberian Pakan Alami dan Pakan Buatan Terhadap Pertumbuhan Ikan Betutu (Oxyeleotris marmomata) Pada Skala Laboratorium. Jurnal Sains dan Seni Pomits, 2(1); 1-5.

Arief M, Triasih I, Paramita WL. 2009. Pengaruh Pemberian pakan Alami dan Pakan Buatan Terhadap Pertumbuhan Benih Ikan Betutu (Oxyeleotris marmorata). Jurnal Ilmiah Perikanan dan Kelautan. Vol: 1;1. 51-57.

Boyd CE. 1991. Enviromental and phsycologycal factors controlling the rproduction cycles of pinnipeds. Can J Zool. 69, 1135-1148.

Boyd CE, Licthkoppler F. 1979. Water Quality Management in Pond Fish Culture. International Center for Aquaculture Agricultural Experiment station. Auburn University.

Cahyaningrum RN, Subandiono, Herawati VE. 2015. Tingkat Pemanraatan Artemia sp. Beku, Artemia sp. Awetan, dan Cacing Sutra Segar Untuk Pertumbuhan dan Kelangsungan Hidup Larva Lele Sangkuriang (Clarias gariepinus). Journal of Aquaculture Management and Technology. Vol: 4 (2); 18-25.

Chilmawati D, Suminto, Tristiana Y. 2015. Pemanfaatan Fermentasi Limbah Organik Ampas Tahu, Bekatul, Dan Kotoran Ayam Untuk Peningkatan
Prouksi Kultur dan Kualitas Cacing Sutera (Tubifex sp.). Pena Jurnal Ilmu Pengetahuan dan Teknologi. 28(2); 186201.

Effendie MI. 1979. Metode Biologi Perikanan. Yayasan Dewi Sri Bogor.

Elliot JM, Hurley MA. 1995. Functional Ecology. Vol: IX. British Ecology Society. P.625-627.

Farhoudi A, Abedian KAM, Nazari RM, Makhdoomi C. 2013. Changes of Digestive Enzymes Activity in Common Carp (Cyprinus carpio) During Larval Ontogeny. Iranian Journal of Fisheries Sciences. 12(2); 320-334.

Hariati E. 2010. Potensi Tepung Cacing Sutera (Tubifex sp.) dan Tepung Potensi Tepung Tapioka Untuk Substitusi Pakan Komersil Ikan Patin (Pangasius hypophtalmus). [SKRIPSI]. Universitas Atma Jaya Yogyakarta. Yogyakarta.

Herliwati. 2012. Variasi Dosis Kotoran Ayam Pada Budidaya Cacing Rambut (Tubifex sp.). Journal Fish Scientiae. Vol: 2(4); 124-130.

Idawati, Defira CN, Mellisa S. 2018. Pengaruh Pemberian Pakan Alami Yang Berbeda Terhadap Pertumbuhan dan Kelangsungan Hidup Benih Ikan Patin (Pangasius sp.). Jurnal Ilmiah Mahasiswa Kelautan dan Perikanan Unsyiah. Vol: 3(1): 14-22.

Jusadi D, Sulasingkin D, Mokoginta I. 2005. pengaruh ragi dengan konsentrasi yang berbeda sebagai pakan terhadap pertumbuhan populasi Daphnia sp. Jurnal Ilmu-ilmu Perairan dan Perikanan Indonesia. Vol: 12(1): 17-21.

Mufidah NBW, Rahardja BS dan Satyantini WH. 2009. Pengkayaan Daphnia sp. dengan Viterna terhadap Kelangsungan Hidup dan Pertumbuhan Larva Ikan Lele Dumbo (Clarias gariepinus). Jurnal Ilmiah Perikanan dan Kelautan. Vol: 1(1) : 1-3.

Nazhiroh N, Mulyana, Mumpuni FS. 2019. Pengaruh Penambahan Tepung Sp.irulina platensis Dalam Pakan Terhadap Pertumbuhan Dan Efisiensi Pakan Ikan Mas Koki (Carassius 
auratus). Jurnal Mina Sains 5(1): 50 57.

Nisrinah, Subandiyono dan T. Elfitasari. 2013. Pengaruh Penggunaan Bromelin terhadap Tingkat Pemanfaatan Protein Pakan dan Pertumbuhan Lele Dumbo (Clarias gariepinus). Jurnal of Aquaculture Management and Technology. 2(2) : 57-63.

Nurhayati, Utomo NBP, Setiawati M. 2014. Perkembangan Enzim Pencernaan dan Pertumbuhan Larva Ikan Lele Dumbo (Clarias gariepinus) yang diberi Kombinasi Cacing Sutera dan Pakan Buatan. Jurnal Ikhtiologi indonesia. 14(3); 167-178.

Pangkey H. 2009. Daphnia dan Penggunaannya. Jurnal Perikanan dan Kelautan. Vol: V( 3): 33-36.

Pangkey H, Ngatung JE, Mokolensang JF. 2018. Budi Daya Cacing Sutera (Tubifex sp.) Dengan Sistem Air Mengalir di Balai Perikanan Budidaya Air Tawar (BPBAT) Tatelu, Sulawesi Utara. Jurnal Budidaya Perairan. Vol:5(3) ; 18-22.

Putra AK, Mumpuni SF, Rosmawati. 2017. Pengaruh Pemberian Pakan Alami yang Berbeda terhadap Pertumbuhan dan Kelangsungan Hidup Benih Ikan Maanvis (Pterophyllum scalare). Jurnal Mina Sains. Vol: 3(1): 30-38.

Rachmawati D, Istiyanto S. 2013. Efektivitas Substitusi Tepung Ikan dengan Tepung Maggot Dalam Pakan Buatan Terhadap Pertumbuhan dan Kelulusanhidupan Ikan Patin (Pangasius pangasius). Jurnal Saintek Perikanan. Vol: 9(1): 6267.

Retnosari, D. 2007. Pengaruh substitusi tepung ikan oleh tepung maggot terhadap pertmbuhan benih nila (Oreochromis niloticus). (Laporan penelitian). Bandung. Fakultas Perikanan dan Ilmu Kelautan, Universitas Panjadjaran.

Rika. 2008. Pengaruh Salinitas terhadap Pertumbuhan dan kelulushidupan Ikan Hasil Strain GIFT dengan Strain Singapura.[Skripsi]. Semarang. Fakultas Perikanan dan Ilmu Kelautan, Universitas Diponegoro.
Sarmudianto E, Rosmawati, Muarif. 2015. Peningkatan Kadar Asam Lemak Omega 3 Pada Daphnia sp. Dengan Pengkayaan Minyak Ikan. Jurnal Mina Sains. Vol: 1 (1): $1-5$.

Satyantini WH, Wibowo HP, Mukti AT. 2008. Pengaruh Kombinasi Pakan Alami Yang Berbeda Terhadap Pertumbuhan dan Kelulusanhidup Larva Ikan Lele Dumbo (Clarias gariepinus). Berkala Ilmiah Perikanan. 3(2): 41-48.

Setyaningrum N, Sugiharto, Sukmaningrum S. 2016. Budidaya Cacing Rambut (Tubifex sp.) Dengan Fermentasi Limbah Organik Sebagai Pakan Alami Larva Ikan Gurami. Prosiding Seminar Nasional dan Call of Papers "Pengembangan Sunberdaya Pedesaan dan Kearifan Lokal Berkelanjutan. Universitas Soedirman.

Steel GD, Torrie JH. 1989. Prinsip Prinsip dan Prosedur Statistika. Jakarta: Terjemahan PT. Gramedia Pustaka Utama.

Suprapto R, Iswanto B, Imron. 2012. Pengaruh Pemberian Pakan Alami Berbeda Terhadap Performa Pertumbuhan dan Sintasan Benih Ikan Lele (Clarias gariepinus). Forum Inovasi Teknologi Akuakultur. 563-572.

Tjodi R, Kalesaran OJ, Watung JC. 2016. Kombinasi Pakan Terhadap Pertumbuhan dan Kelangsungan Hidup Larva Ikan Lele Sangkuriang (Clarias gariepinus). Jurnal Budidaya Perairan. Vol: 4(2): 1-7.

Triyanto H, Rosmawati, Widiyati A. 2016. Kebutuhan Jumlah Pakan Pada Pemeliharaan Ikan Tengadak (Barbonymus schwanenfeldii) di Kolam. Jurnal Mina Sains. Vol: 2(1): 45-52.

Zonneveld, Huisman NEA dan Boon JH.1991. Prinsip-Prinsip Budidaya Ikan. Terjemahan. PT. Gramedia Pustaka Utama. Jakarta. 318p. 